\title{
Seasonal and spatial distribution of fish larvae in waters over the North West Continental Shelf of Western Australia
}

\author{
P. C. Young ${ }^{1}$, J. M. Leis ${ }^{2} \&$ H. F. Hausfeld ${ }^{1}$ \\ ' Division of Fisheries Research, CSIRO Marine Laboratories, GPO Box 1538, Hobart, Tasmania 7001, Australia \\ ${ }^{2}$ Division of Vertebrate Zoology, Australian Museum, 6-8 College Street, Sydney, N.S.W. 2000, Australia
}

\begin{abstract}
Distributional patterns of larval fishes in the waters of the North West Continental Shelf of Australia and the adjacent open ocean were examined in a series of stepped, oblique mid-water trawled samples to $100 \mathrm{~m}$. These were taken from September 1982 to October 1983 at fixed sites distributed across 2 cross-shelf transects, the longer western transect extending to a water depth of $1000 \mathrm{~m}$, the eastern transect extending to the shelf break at approximately $140 \mathrm{~m}$. Larvae were, with a few exceptions, identified to family, and 104 taxa were used for subsequent analyses. The pooled larvae were least concentrated at the shelf break, becoming denser towards both the shore and towards the ocean. Mean concentration of larvae (all species pooled) varied with time at the 3 pairs of innermost sites. Concentrations increased in June at the 4 midshelf sites, but decreased at the inner shelf sites until August. Classificatory analyses, based on the presence or absence of each of the 104 taxa in all samples, distinguished a major discontinuity in faunal composition just inshore of the shelf break. Other differences in faunal structure (in order of size) pertained to type of sampling gear, depth of sampling site and time of year of sampling. Short-term differences ( $2 \mathrm{wk}$ periods) were not detected, nor was any consistent longshore variability. Characteristic of the deeper sites were those taxa found as adults on the continental slope and open ocean, whereas larvae of taxa that occupied the shelf as adults were characteristic of the shelf sites. The pattern of larval distributions were in general agreement with previous studies from the Pacific Coast of North America. Apart from a summer/winter change in both water conditions and larval taxon frequencies, little correlation was found between larval distribution or abundance and the hydrography of the area.
\end{abstract}

\section{INTRODUCTION}

As part of a study of the demersal fishes of the continental shelf of Northern Australia, CSIRO Division of Fisheries Research began a multidisciplinary study of the North West Continental Shelf of Western Australia (Indian Ocean) in 1982. The study focused on the distribution, abundance and biology of adult fish species and seasonal changes in the distribution of the larval fishes of the region.

The aims of the larval fish study were to detect the major patterns of distribution of larval fishes both across and along the continental shelf; to examine variability in larval fish abundance and distributional patterns in both the short term (about $2 \mathrm{wk}$ ), and the long term ( 1 yr); and to relate the distribution of larvae to the principal characteristics of the water column.
Results were compared with those of other larval fish studies.

In the present paper we described the broad distributional patterns of the fish larvae in both space and time. The analysis is at the family level. Later publications will relate the distribution of the larvae of individual species to the distribution and reproductive biology of adults as revealed by concurrent studies.

\section{MATERIALS AND METHODS}

Fish larvae sampling. Ten sites were sampled every second month, from September 1982 to October 1983. The sites were situated on 2 cross-shelf transects. Each transect consisted of 4 sites over the continental shelf, with 2 additional sites on the western transect beyond 
Fig. 1. Location of sampling sites

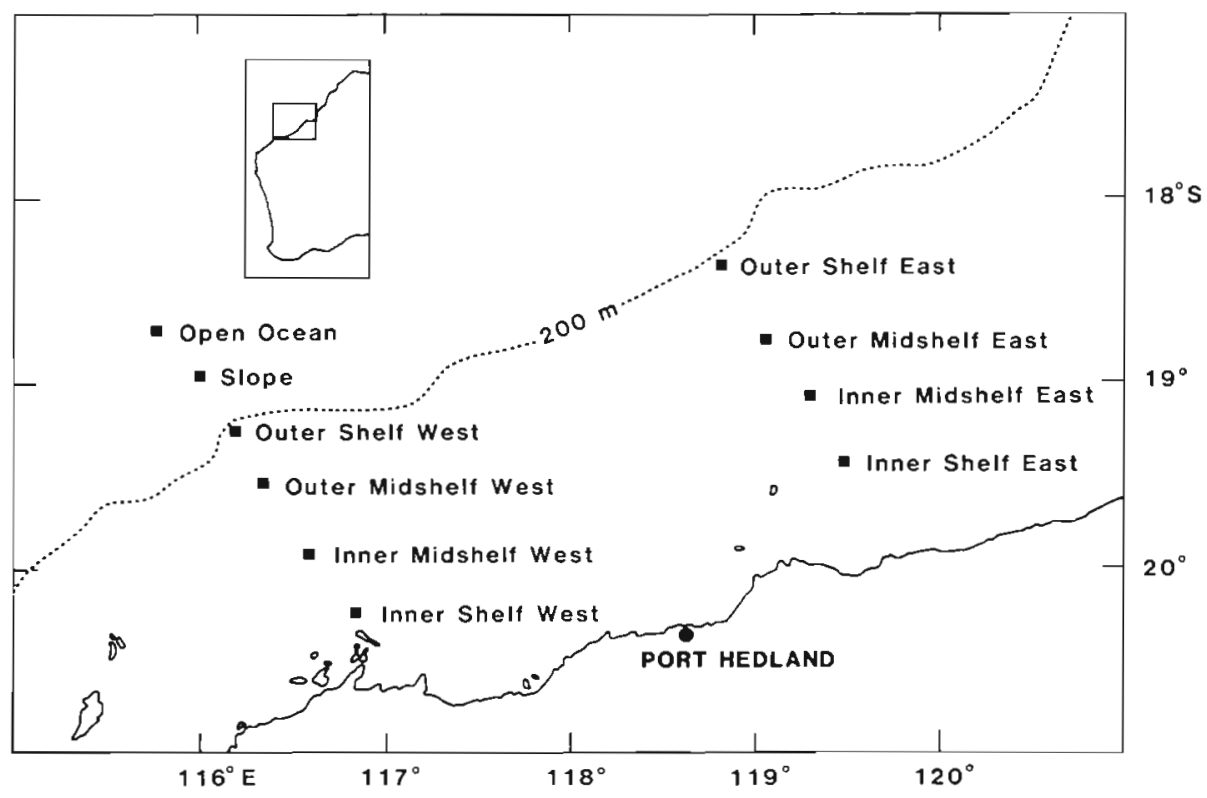

the shelf edge (Fig. 1). During each cruise, the 4 innermost western shelf sites were usually sampled in triplicate on each of 2 occasions about 2 wk apart, while the other sites were sampled in triplicate once only. The sampling order of the sites varied for each cruise because of the need to use the ship for other, related activities. The position, bottom depth and distance from shore of each site are shown in Table 1.

The sampling nets planned for use in this program were not available at its start, so a substitute was used, resulting in 2 stages in the sampling programme. The first 2 cruises (28 September to 13 October 1982, 19 November to 15 December 1982) used a Maruchi A larval fish net (Nakai 1962) with a diameter of $130 \mathrm{~cm}$, $2 \mathrm{~mm}$ mesh and a $0.33 \mathrm{~mm}$ cod-end with a TSK 8 -mile flowmeter. The subsequent 5 cruises (23 January to 29
October 1983) used a $1.8 \mathrm{~m}$ modified Isaacs-Kidd Midwater Trawl with a mouth area of $2.89 \mathrm{~m}^{2}, 2 \mathrm{~mm}$ mesh throughout (Smith \& Richardson 1977) and a Rigosha flowmeter Model 2536B. The average towing speeds for the 2 nets were $1.2( \pm 0.3) \mathrm{m} \mathrm{s}^{-1}$ and $2.3( \pm 0.4)$ $\mathrm{m} \mathrm{s}^{-1}$, respectively.

The tows were obliquely stepped, with steps at $5 \mathrm{~m}$ intervals and of equal duration for a haul. Samples were taken to as near the bottom as possible, or to a depth of approximately $100 \mathrm{~m}$ (as measured by wire angle) whichever was less. All samples were taken after dark (between $1 \mathrm{~h}$ after sunset and $1 \mathrm{~h}$ before dawn) and the tow duration ranged from 15 to $20 \mathrm{~min}$, depending on the depth. The volume of water filtered during each tow was calculated using the flowmeter readings. Samples from the 3 replicate tows were pre-

Table 1. Location, depth, and distance from shore of sampling sites

\begin{tabular}{|c|c|c|c|c|c|}
\hline Site & Site & \multicolumn{2}{|c|}{ Position } & Average depth & Distance from shore \\
\hline \multicolumn{6}{|c|}{ Western transect } \\
\hline 1 & Inner shelf & $20^{\circ} 15^{\prime} \mathrm{S}$ & $116^{\circ} 50^{\prime} \mathrm{E}$ & 41 & 17 \\
\hline 2 & Inner midshelf & $19^{\circ} 55^{\prime} \mathrm{S}$ & $116^{\circ} 35^{\prime} \mathrm{E}$ & 58 & 39 \\
\hline 3 & Outer midshelf & $19^{\circ} 32^{\prime} \mathrm{S}$ & $116^{\circ} 20^{\prime} \mathrm{E}$ & 110 & 66 \\
\hline 4 & Outer shelf & $19^{\circ} 15^{\prime} \mathrm{S}$ & $116^{\circ} 10^{\prime} \mathrm{E}$ & 207 & 84 \\
\hline 5 & Slope & $19^{\circ} 00^{\prime} \mathrm{S}$ & $116^{\circ} 00^{\prime} \mathrm{E}$ & 354 & 103 \\
\hline \multirow[t]{2}{*}{6} & Open ocean & $18^{\circ} 45^{\prime} \mathrm{S}$ & $115^{\circ} 45^{\prime} \mathrm{E}$ & 1000 & 123 \\
\hline & \multicolumn{5}{|c|}{ Eastern transect } \\
\hline 8 & Inner shelf & $19^{\circ} 25^{\prime} \mathrm{S}$ & $119^{\circ} 30^{\prime} \mathrm{E}$ & 49 & 36 \\
\hline 9 & Inner midshelf & $19^{\circ} 05^{\prime} \mathrm{S}$ & $119^{\circ} 20^{\prime} \mathrm{E}$ & 73 & 54 \\
\hline 10 & Outer midshelf & $18^{\circ} 45^{\prime} \mathrm{S}$ & $119^{\circ} 05^{\prime} \mathrm{E}$ & 109 & 72 \\
\hline 11 & Outer shelf & $18^{\circ} 20^{\prime} \mathrm{S}$ & $118^{\circ} 50^{\prime} \mathrm{E}$ & 131 & 99 \\
\hline
\end{tabular}


served in $10 \%$ seawater formalin, and the fish larvae were later transferred to $70 \%$ ethanol. Fish larvae were sorted from each sample, identified to family level where possible, and then counted. The Clupeoidei (except the Dussumieriinae), the Pleuronectiformes, eel leptocephali, and Lophiiformes were not identified to family. As the Epinepheline were of special interest because of associated studies in other locations, individuals of the family Serranidae were identified to subfamily levels. Larvae that were too small or too damaged to be identified easily were mostly from the Maruchi net and were not used in numerical analyses. The 'mullid-like' larvae comprised individuals of similar pigmentation to mullid larvae but with only a single dorsal fin; possibly they were pomacentrids. The main references used for identification were Fahay (1983), Leis \& Rennis (1983) and Volumes I to VI of 'Development of Fishes of the midAtlantic Bight' (Jones et al. 1978, Hardy 1978a, b, Johnson 1978, Fritzsche 1978, Martin \& Drewry 1978). Concentrations were calculated prior to analysis as the number of larvae per $10000 \mathrm{~m}^{3}$ of water filtered. The number and type of taxa in each sample from different nets and volumes of water filtered were not standardised prior to classification since any relation between the number of taxa and water volume filtered has to be derived empirically.

Hydrological sampling. Concurrently with fish larvae sampling, water was collected by Nansen casts at predetermined depths. Those used in the present analysis were: from the surface to the bottom at $10 \mathrm{~m}$ intervals at the inner shelf and inner and outer midshelf sites; the surface, $10 \mathrm{~m}, 25 \mathrm{~m}$ and thereafter at $25 \mathrm{~m}$ intervals at the outer shelf sites; the surface, $10 \mathrm{~m}$, $25 \mathrm{~m}$, and then $25 \mathrm{~m}$ intervals to $100 \mathrm{~m}$ at the slope site; and from the surface to $100 \mathrm{~m}$ at $25 \mathrm{~m}$ intervals at the open ocean site. The water was analysed for chlorinity, temperature, oxygen, nitrate, silicate, and in vivo fluorescence. The last was used as a gross indicator of phytoplankton standing stock (Parker \& Vaudrey 1980). Each of these variables was averaged through the water column to a depth of $100 \mathrm{~m}$, or the bottom, whichever came first, and thereafter subjected to analysis. Since the larval fish were from throughout the sampled water column, and could therefore not be separated into depth strata, this form of column averaging and data analysis was considered most appropriate to relate water conditions to catches of larval fish.

Analytical methods. The initial analysis of fish according to the presence or absence of all taxa in

\footnotetext{
1 Full details of the classificatory programs used in the analyses may be obtained from CSIRO Division of Computing Research, GPO Box 1800, Canberra, ACT 2601, Australia
}

replicate samples involved a polyethic agglomerative classification ${ }^{1}$, using the information gain on fusion of 2 samples as a measure of dissimilarity. The information gain was calculated according to Williams et al. (1966) for binary data. Following statistical validation that the classification was revealing real relations, by the method of Sandland \& Young (1979a, b), binary scores for each taxon from replicate samples were pooled, giving for each pooled sample a vector of taxa scores, each lying between 0 and 3 . These modified data were then reclassified, using the previous polyethic agglomerative technique but with the information algorithm appropriate to frequency data in which the attributes are used as multistate variables (Dale et al. 1971). Taxa contributing most to the differences between various groups of samples that had been distinguished by the classificatory procedure were extracted using the method of Lance et al. (1968).

Analysis of water column properties (chlorinity, temperature, oxygen etc.) followed a similar classificatory procedure using their column-averaged values for each site/time as attributes. The Gower Metric as described by Lance \& Williams (1967a) was used as a measure of dissimilarity and samples were sorted into a dendrogram using the unweighted group average (Lance \& Williams 1967 b).

\section{RESULTS}

\section{Fish larvae}

The change in net type between the first 2 cruises and the subsequent 5 produced a number of problems in data analysis, and detracted from the time series aspects of the investigation. The Maruchi net was smaller, had a much smaller cod-end mesh size and was towed more slowly than the Isaacs-Kidd net. It retained smaller larvae of a given taxa and consequently up to 10 times more larval fish per unit volume of water sampled. The catch also held more individuals of those taxa in which the larvae are relatively slender or small when they settle from the pelagic environment. Therefore it is not possible to ascribe the differences in fauna from samples obtained by the 2 different nets to dissimilarities in the populations from which they were derived.

Altogether, 104 taxa were identified in the samples. Overall, the pleuronectiform group was most abundant, with 6748 individuals. By contrast, 12 families were represented by only a single specimen. The taxa and the number of individuals in each are given in Table 2.

Analysis of variance of the variability in larval concentration (number of all species per unit volume sam- 
Table 2. Taxa of larval fish encountered in samples from the North West Shelf, the number of each caught, and their mean concentrations (number per $10000 \mathrm{~m}^{3}$ ), in each group of samples defined by the classificatory analysis and shown in Fig. 3

\begin{tabular}{|c|c|c|c|c|c|c|c|c|c|c|}
\hline \multirow[t]{2}{*}{ Taxon } & \multirow{2}{*}{$\begin{array}{l}\text { Numbers } \\
\text { caught }\end{array}$} & \multirow{2}{*}{$\begin{array}{l}\text { Principal habitat } \\
\text { of aduits }\end{array}$} & \multicolumn{8}{|c|}{ Mean concentration in each sample group $\left(\mathrm{n} 10000 \mathrm{~m}^{-3}\right)$} \\
\hline & & & L1 & L2 & L3 & L4 & L5 & L6 & L7 & L8 \\
\hline Pleuronectiformes & 6748 & Shelf & 44.1 & 3.5 & 170.4 & 467.0 & 14.9 & 50.1 & 34.3 & 34.2 \\
\hline Gobiidae & 4614 & Shelf & 61.7 & 0.1 & 213.0 & 865.2 & 2.4 & 3.3 & 8.2 & 0.9 \\
\hline Eel leptocephali & 4292 & Shelf & 65.2 & 26.6 & 39.2 & 255.8 & 10.1 & 16.7 & 13.0 & 4.3 \\
\hline Carangidae & 4012 & Shelf/ocean/slope & 161.8 & 0.4 & 12.6 & 625.8 & 6.0 & 4.4 & 13.8 & 0.9 \\
\hline Clupeoidei & 3230 & Shelf & 2.0 & - & 27.2 & 587.3 & 4.7 & 1.2 & 1.8 & 34.2 \\
\hline Apogonidae & 3058 & Shelf & 15.5 & 0.1 & 106.7 & 195.5 & 5.4 & 28.7 & 25.8 & 4.6 \\
\hline Myctophidae & 2739 & Ocean/slope & 234.6 & 12.3 & 28.7 & 15.2 & 0.5 & 0.9 & - & - \\
\hline Scombridae & 2672 & Shelf/ocean/slope & 64.4 & 0.1 & 2.1 & 670.0 & 1.0 & 1.0 & 3.0 & 0.1 \\
\hline Lutjanidae & 2276 & Shelf & 91.3 & 0.2 & 16.4 & 156.8 & 5.6 & 11.2 & 18.0 & 1.5 \\
\hline Synodontidae & 1792 & Shelf & 17.9 & 0.5 & 77.5 & 115.7 & 6.9 & 9.6 & 5.0 & 2.1 \\
\hline Bregmacerotidae & 1437 & Shelf/ocean/slope & 26.0 & 0.4 & 35.6 & 48.3 & 8.1 & 6.9 & 5.0 & 4.7 \\
\hline Gonostomatidae & 1332 & Ocean/slope & 140.8 & 2.2 & 11.7 & 0.3 & - & 0.3 & - & 0.1 \\
\hline Schindleriidae & 924 & Shelf & 1.7 & - & 36.2 & 219.0 & 0.5 & 0.5 & - & 0.1 \\
\hline Mullidae & 900 & Shelf & 10.1 & - & 9.8 & 1.7 & 3.1 & 10.6 & 10.0 & 0.4 \\
\hline Nemipteridae & 889 & Shelf & 10.2 & - & 32.1 & 118.3 & 0.3 & 4.6 & 3.8 & - \\
\hline Champsodontidae & 819 & Shelf & 8.7 & 0.2 & 6.5 & 32.5 & 4.0 & 6.4 & 4.0 & 2.8 \\
\hline 'Mullid-like' & 808 & Shelf & 7.8 & - & 11.2 & 80.2 & 0.5 & 9.1 & 3.5 & 0.2 \\
\hline Pomacentridae & 784 & Shelf & 1.2 & - & 7.9 & 24.2 & - & 15.0 & 2.3 & 0.3 \\
\hline Lethrinidae & 757 & Shelf & 14.3 & - & 22.6 & 26.3 & 0.9 & 7.4 & 3.0 & 0.8 \\
\hline Monacanthidae & 750 & Shelf & 3.6 & 0.2 & 6.7 & 40.2 & 0.7 & 5.3 & 9.3 & 6.8 \\
\hline Priacanthidae & 659 & Shelf & 59.2 & - & 0.7 & 8.8 & 1.6 & 1.1 & 0.5 & - \\
\hline Leiognathidae & 592 & Shelf & 0.4 & - & 35.6 & 35.7 & 4.6 & 1.8 & 1.2 & - \\
\hline Scorpaenidae & 545 & Shelf & 3.5 & 0.1 & 7.8 & 51.5 & 0.7 & 5.1 & 1.7 & 1.7 \\
\hline Epinephelinae & 519 & Shelf & 7.7 & 0.1 & 13.7 & 19.2 & 2.7 & 2.6 & 6.7 & 0.3 \\
\hline Triglidae & 431 & Shelf & 0.8 & - & 2.2 & 1.2 & 0.1 & 9.0 & 0.3 & 0.8 \\
\hline Labridae & 396 & Shelf & 4.5 & - & 34.2 & 28.5 & 0.1 & 2.1 & - & 0.1 \\
\hline Paralepididae & 344 & Shelf & 27.1 & 0.4 & 6.5 & 0.3 & 0.8 & 0.8 & - & - \\
\hline Platycephalidae & 311 & Shelf & 5.3 & - & 3.8 & 49.8 & 0.1 & 1.9 & 1.3 & 0.2 \\
\hline Dussumierinae & 277 & Shelf & 9.3 & - & 9.5 & 34.2 & - & 0.2 & 1.0 & - \\
\hline Tetraodontidae & 261 & Shelf & 2.0 & - & 15.6 & 42.2 & 0.1 & 0.4 & 0.7 & - \\
\hline Haemulidae & 192 & Shelf & 0.5 & - & 9.4 & 45.8 & - & - & 0.3 & - \\
\hline Blenniidae & 176 & Shelf & 1.3 & - & 3.4 & 24.3 & 0.1 & 1.5 & 0.3 & - \\
\hline Fistulariidae & 165 & Shelf & 1.2 & - & 0.3 & 7.6 & 0.6 & 1.4 & 2.5 & 0.7 \\
\hline Sphyraenidae & 152 & Shelf & 6.6 & - & 0.5 & 27.7 & - & - & 0.5 & 0.1 \\
\hline Opistognathidae & 143 & Shelf & 0.6 & - & 8.0 & 39.0 & - & - & - & - \\
\hline Microdesmidae & 127 & Shelf & 4.0 & - & 7.0 & 16.0 & - & 0.1 & - & - \\
\hline Acanthuridae & 123 & Shelf & 1.9 & 0.1 & - & 1.7 & 2.7 & 0.1 & - & - \\
\hline Nomeidae & 120 & Ocean/slope & 5.7 & 0.1 & 0.5 & 0.2 & 0.2 & 0.9 & - & 0.1 \\
\hline Balistidae & 119 & Shelf & 0.3 & - & - & 3.3 & 1.0 & 0.1 & 4.8 & 0.3 \\
\hline Anthiinae & 116 & Shelf & 3.8 & - & 0.5 & 13.2 & 0.1 & 0.9 & 0.2 & - \\
\hline Siganidae & 107 & Shelf & 3.7 & - & 2.5 & - & - & 2.0 & 0.3 & 0.7 \\
\hline Callionymidae & 97 & Shelf & - & - & 6.3 & 5.7 & 0.1 & 0.1 & 0.3 & - \\
\hline Gempylidae & 95 & Ocean/slope & 6.9 & 0.3 & 0.4 & - & 0.1 & 0.2 & - & - \\
\hline Cephalocanthidae & 77 & Shelf & 4.7 & - & 0.3 & 4.5 & 0.2 & 0.4 & 0.2 & - \\
\hline Trichiuridae & 77 & Shelf/ocean/slope & 0.7 & - & 0.6 & 8.5 & 0.5 & 0.5 & - & 0.1 \\
\hline Uranoscopidae & 75 & Shelf & 0.3 & - & 2.1 & 1.8 & - & 0.5 & 1.5 & - \\
\hline Carapidae & 73 & Shelf & 1.3 & 0.2 & 1.5 & 3.7 & 0.3 & 0.4 & 0.2 & 0.1 \\
\hline Pomacanthidae & 67 & Shelf & 1.2 & - & 0.6 & 8.0 & 0.1 & 0.5 & 0.3 & 0.1 \\
\hline Creediidae & 60 & Shelf & 0.8 & - & 4.3 & 7.3 & - & - & - & - \\
\hline Ammodytidae & 54 & Shelf & 0.9 & - & 0.4 & 8.8 & 0.1 & 0.1 & - & - \\
\hline Bramidae & 51 & Ocean/slope & 3.6 & 0.2 & - & - & - & 0.2 & - & - \\
\hline Melanostomiatidae & 50 & Ocean/slope & 3.3 & 0.4 & 0.6 & - & 0.1 & - & - & - \\
\hline Syngnathidae & 48 & Shelf & - & - & 0.6 & 1.8 & - & 0.4 & 0.5 & 0.6 \\
\hline Hemiramphidae & 47 & Shelf & 4.3 & 0.1 & 0.1 & 0.3 & 0.1 & - & 0.2 & - \\
\hline Percichthyidae & 47 & Shelf/ocean/slope & 3.5 & 0.1 & 0.3 & 1.2 & 0.1 & - & - & - \\
\hline Holocentridae & 46 & Shelf & 1.6 & - & - & - & 0.8 & - & - & - \\
\hline Ophidiidae & 44 & Shelf & 3.0 & - & 0.6 & 0.3 & - & 0.2 & - & - \\
\hline Trichonotidae & 43 & Shelf & 0.3 & - & 1.2 & 7.3 & - & - & 0.3 & 0.1 \\
\hline Caproidae & 40 & Shelf & 4.1 & - & - & 0.8 & - & $=$ & - & - \\
\hline
\end{tabular}


Table 2 (continued)

\begin{tabular}{|c|c|c|c|c|c|c|c|c|c|c|}
\hline \multirow[t]{2}{*}{ Taxon } & \multirow{2}{*}{$\begin{array}{l}\text { Numbers } \\
\text { caught }\end{array}$} & \multirow{2}{*}{$\begin{array}{l}\text { Principal habitat } \\
\text { of adults }\end{array}$} & \multicolumn{8}{|c|}{ Mean concentration in each sample group $\left(\mathrm{n} 10000 \mathrm{~m}^{-3}\right)$} \\
\hline & & & L1 & $\mathrm{L} 2$ & L3 & $\mathrm{L} 4$ & L5 & L6 & L7 & L8 \\
\hline Pempherididae & 40 & Shelf & 0.1 & - & 3.1 & 0.3 & - & 0.3 & 0.5 & 0.1 \\
\hline Menidae & 37 & Shelf & - & - & - & 6.5 & 0.1 & 0.1 & - & - \\
\hline Gerreidaedae & 35 & Shelf & 0.3 & - & 0.2 & 8.5 & - & - & 0.2 & - \\
\hline Coryphaenidae & 34 & Ocean/slope & 3.7 & - & 0.1 & 0.3 & - & - & - & - \\
\hline Mugiloididae & 31 & Shelf & 0.4 & - & 1.8 & 5.5 & - & - & - & - \\
\hline Pegasidae & 29 & Shelf & 1.0 & - & 2.8 & 0.3 & - & 0.1 & - & - \\
\hline Scaridae & 29 & Shelf & 0.2 & - & 3.1 & 2.5 & - & - & - & - \\
\hline Lophiiformes & 24 & Shelf/ocean/slope & 1.3 & - & 0.3 & 0.7 & - & 0.1 & - & 0.1 \\
\hline Notosudidae & 23 & Ocean/slope & 1.3 & 0.1 & 0.8 & - & 0.1 & - & - & 0.1 \\
\hline Melamphaidae & 23 & Ocean/slope & 2.7 & - & 0.4 & - & - & - & - & - \\
\hline Chaetodontidae & 20 & Shelf & 0.3 & - & - & 3.0 & 0.1 & - & - & - \\
\hline Evermannellidae & 20 & Ocean/slope & 2.3 & - & 0.2 & - & - & - & - & - \\
\hline Scopelarchidae & 18 & Ocean/slope & 0.9 & 0.1 & 0.1 & - & - & - & - & - \\
\hline Pseudochromidae & 17 & Shelf & - & - & 0.5 & 4.8 & - & - & - & 0.1 \\
\hline Cepolidae & 14 & Shelf & 0.3 & - & 0.7 & 1.7 & - & - & - & - \\
\hline Cirrhitidae & 13 & Shelf & 0.2 & - & 0.1 & 0.3 & - & 0.1 & - & - \\
\hline Exocoetidae & 11 & Shelf/ocean/slope & 0.6 & - & 1.2 & - & - & - & - & 0.1 \\
\hline Branchiostegidae & 7 & Shelf & 0.7 & - & - & - & - & - & - & - \\
\hline Amarsipidae & 7 & Ocean/slope & 0.1 & - & - & - & - & 0.1 & - & - \\
\hline Centriscidae & 6 & Shelf & - & - & - & 1.7 & - & - & - & - \\
\hline Stomiatidae & 6 & Ocean/slope & 0.2 & - & - & - & - & - & - & -- \\
\hline Diodontidae & 5 & Shelf & - & - & - & - & - & - & - & 0.1 \\
\hline Istiophoridae & 5 & Ocean/slope & 0.3 & - & - & - & - & - & - & - \\
\hline Regalecidae & 5 & Ocean/slope & 0.1 & - & - & - & - & - & - & - \\
\hline Chlorophthalmidae & 5 & Ocean/slope & 0.3 & - & - & - & - & - & - & - \\
\hline Atherinidae & 4 & Shelf & - & - & 0.2 & - & - & - & 0.2 & - \\
\hline Formionidae & 4 & Shelf & - & - & - & 1.1 & - & - & - & - \\
\hline Chiasmodontidae & 4 & Shelf & 0.5 & - & - & - & - & - & - & - \\
\hline Sparidae & 4 & Shelf & - & - & 2.3 & - & - & - & - & - \\
\hline Ostracuidae & 3 & Shelf & 0.1 & - & - & 0.3 & - & - & - & - \\
\hline Elopidae & 3 & Shelf & 0.1 & - & - & 0.3 & - & - & - & - \\
\hline Diretmidae & 3 & Shelf & 0.3 & - & - & - & - & - & - & - \\
\hline Soelnostomidae & 2 & Shelf & - & - & - & - & - & - & - & - \\
\hline Tetragonuridae & 1 & Ocean/slope & 0.2 & - & - & - & - & - & - & - \\
\hline Grammistidae & 1 & Shelf & - & - & - & - & - & - & - & - \\
\hline Albulidae & 1 & Shelf & - & - & - & - & - & - & - & - \\
\hline Triacanthidae & 1 & Shelf/ocean/slope & - & - & - & - & - & - & - & - \\
\hline Xiphiidae & 1 & Ocean/slope & 0.1 & - & - & - & - & - & - & - \\
\hline Chauliodontidae & 1 & Ocean/slope & - & - & - & - & - & - & - & - \\
\hline Molidae & 1 & Ocean/slope & - & - & - & - & - & - & - & - \\
\hline Echeneidae & 1 & Ocean/slope & - & - & - & - & - & - & - & - \\
\hline Trachipteridae & 1 & Ocean/slope & - & - & - & - & - & - & - & - \\
\hline Belonidae & 1 & Shelf & - & - & - & - & - & - & - & - \\
\hline Ipnopidae & 1 & Ocean/slope & - & - & - & - & - & - & - & - \\
\hline Melanocetidae & 1 & Ocean/slope & 0.1 & - & - & - & - & - & - & - \\
\hline Unidentified & 1062 & & & & & & & & & \\
\hline Total & 53367 & & & & & & & & & \\
\hline
\end{tabular}

pled) between the factors sites, depths, transects, cruises, and legs on cruises, showed significant differences for all the main factors with the exception of the differences between transects. First order interactions between all factors were also significant. Because the combination of missing samples and changes in net type contributed greatly to these significant interac- tions, we present only the major consistent changes in concentration; similarly, temporal changes in concentration recorded on the first 2 cruises are not compared with those from the later 5 . The mean concentrations and their standard deviations from all replicates, from both transects and both legs on each cruise at each sampling site (inner shelf, inner midshelf, etc.) were 
calculated for the samples from the 5 Isaacs-Kidd cruises. These showed lowest larval concentrations at the outer shelf site, thereafter increasing towards both the shore and open ocean. The mean concentration was greatest at the inner shelf and inner midshelf from January to April (Fig. 2a, b). In June, the mean concentration declined markedly at the inner shelf sites, while it increased at both midshelf sites (Fig. 2c). By August, the mean larval fish concentrations at the inner shelf and inner midshelf sites had reached the greatest recorded during the 5 Isaacs-Kidd cruises. At the same time, the mean concentration of the outer midshelf sites was declining (Fig. 2d); by October, the previous (January to April) pattern of lower concentra-
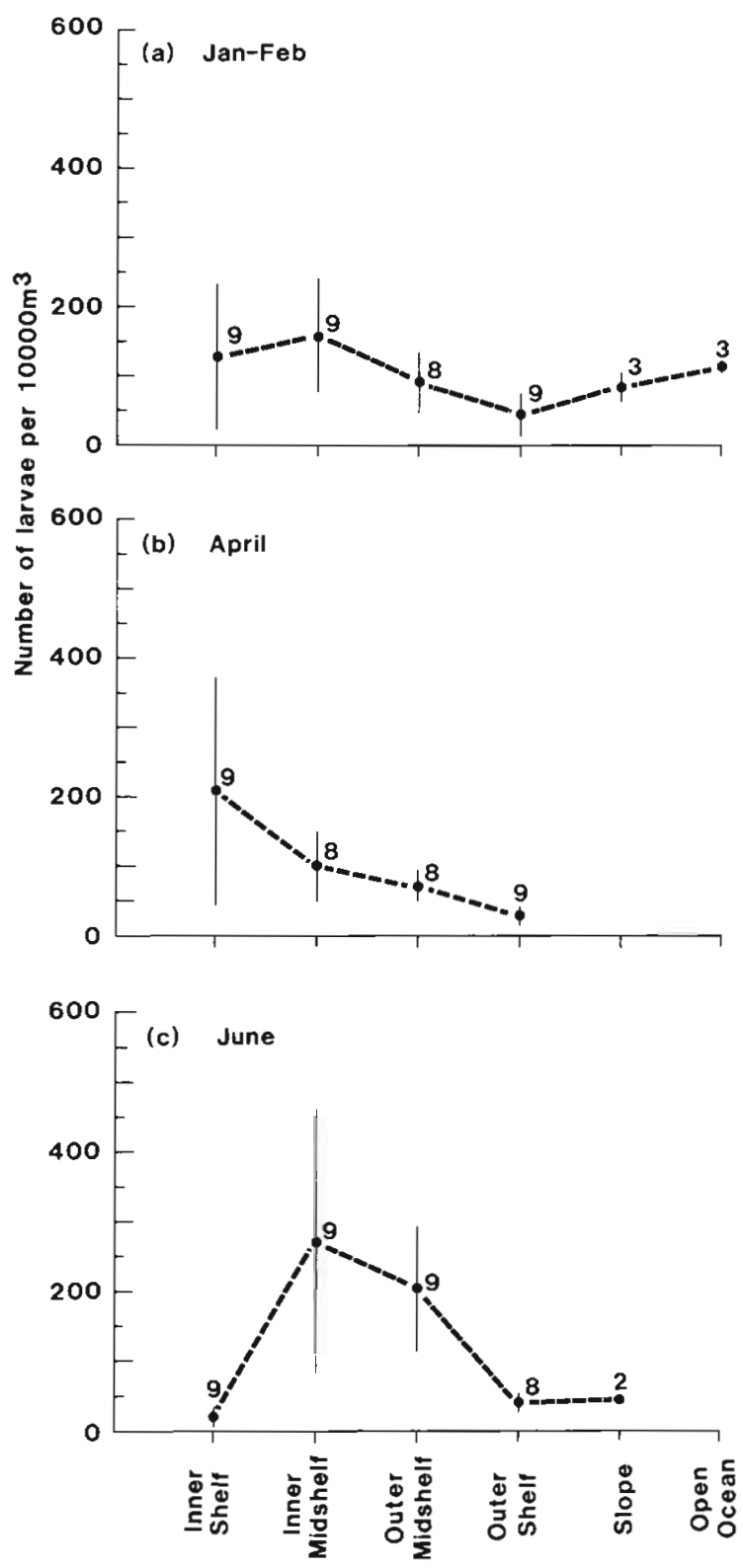

tion at the outershelf site had been re-established (Fig. 2e).

An initial classification of all the samples, based on the presence or absence of each replicate of each of the 104 taxa caught, showed that 34 groups of samples were significantly different from each other by the test of Sandland \& Young $(1979 a, b)$. This implies a high level of internal coherency within replicates, compared with that between sites or times, thus confirming that real differences were being classified, and justifying a second classification on pooled replicates to minimise between-replicate 'noise'. For the sake of clarity, each of these sets will be treated and referred to hereafter as a single sample.

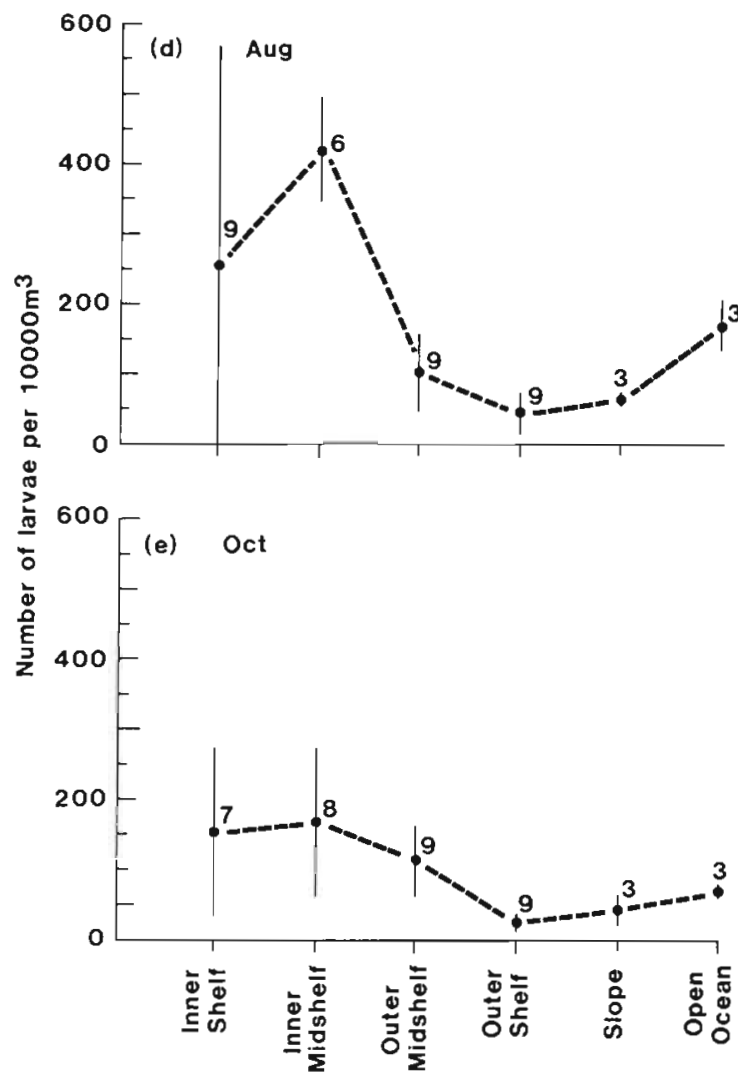

Fig. 2. Mean concentration, and its standard deviation of ichthyoplankton from Isaacs-Kidd samples at each sampling site (replicates and transects pooled for each cruise) 
The second classification showed essentially the same pattern of grouping as did the previous, binary classification, and all the following results and discussion relate to it. It confirmed that there was a major dichotomy (labelled ' $A$ ' in Fig. 3a) in the faunal composition between the samples from deep sites fouter shelf, slope and open ocean), and those from inner and midshelf sites. The dissimilarity due to such elements as gear, depth, and time of sampling appeared at a lower level in the dendrograms. Samples from deep sites were divided further ('B') into a group taken by Isaacs-Kidd net and a group taken mostly by the Maruchi net (which included 2 samples taken on the outer shelf by Isaacs-Kidd net in late October).

The taxa most responsible for the differences in samples from deepwater sites and those from other sites included 5 that typified the samples from deeper
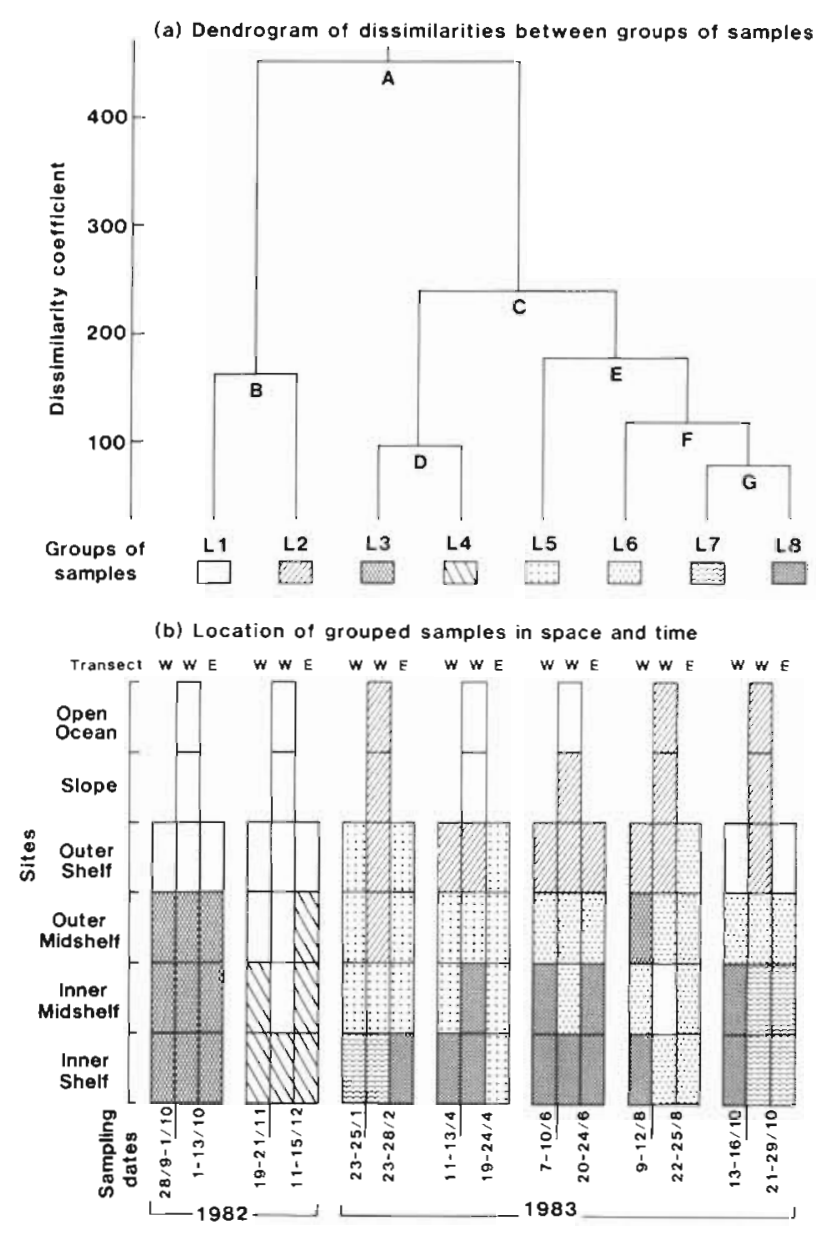

Fig. 3. Classification of the frequency of occurrence of larval fish pooled across replicates. (a) Dendrogram of dissimilarities. (b) Location and time of occurrence of groups of similar samples extracted by the classification. The cells in the columns represent each set of pooled replicate samples. Those in columns marked $W$ come from the western transect Those in columns marked $\mathrm{E}$ come from the eastern transect. sites and are oceanic as adults: Gonostomatidae, Myctophidae, Gempylidae, Coryphaenidae and Melanostomiatidae. The 16 taxa that typified the shallower sites are shelf demersal or neritic in distribution as adults (Table 3 ).

Differences between the 2 groups of samples taken by the Maruchi net ( $\mathrm{L} 1$ in Fig. 3a, b) and the IsaacsKidd net (L2) at the deep sites were due principally to larvae of inner and midshelf fishes (i.e. types of larvae relatively rare in offshelf samples) which were more often caught in the smaller mesh of the Maruchi net cod-end. Differences in the catching ability of the 2 nets confound potential differences due to seasonal factors

Almost 3 times as many taxa were present in the deep-water samples taken principally by the Maruchi net (L1) than were present in the Isaacs-Kidd samples (L2). The concentrations of larvae were also higher (often by an order of magnitude, e.g. Carangidae, Table 2). However, the same 3 taxa (Myctophidae, Gonostomatidae, and eel leptocephali) were among the 5 most abundant types of larvae in both sample groups. The other 2 most abundant taxa were the Carangidae and Lutjanidae (in the Maruchi net group) and the Pleuronectiformes and Synodontidae (in the Isaacs-Kidd group). Although these differences may have been due to seasonal effects, it is more likely that they were due to the differences in net type.

The remaining samples were all from shelf sites and these also separated (with a single exception) at the next level ('C') of the classification, into a group of samples collected by the Maruchi net (L3, L4) and a group collected by the Isaacs-Kidd net (L5, L6, L7, L8; Fig. 3a, b). Again the Maruchi net group of samples was characterised by higher frequencies of occurrence of larvae, all of which were shelf taxa. As with the deep-water samples, the small or slender larvae (particularly those of Microdesmidae, Dussumieriinae and Nemipteridae) were caught in greater numbers by the Maruchi net. Table 3 compares the frequency with which taxa were caught in the different nets.

The next split ('D') in the dendrogram (Fig. 3a) in the group of samples collected from inner and midshelf water by the Maruchi net discriminated between all samples collected in September-October 1982 (L3) and those collected in November-December 1982 (L4). With the exception of the 2 oceanic families Conostomatidae and Myctophidae, the larvae responsible for $50 \%$ of this dissimilarity were more often caught in the November-December (L4) samples. All were shelf taxa (Table 3). An increase in mean concentration within taxa also occurred in November-December (Table 2); it included many common taxa that had shown no increase in frequency due to their presence in almost all samples. By contrast, the larvae of the 
Table 3. Diagnostic taxa contributing most (50\%) to the differences between sample groups described by the classification (Fig. 3). $\because$ : more frequent in first group(s) of comparison + : more frequent in second group(s) of comparison

Taxon

Sample group comparisons

$\begin{array}{ccccccc}\mathrm{L} 1+\mathrm{L} 2 & \mathrm{~L} 1 & \mathrm{~L} 3+\mathrm{L} 4 & \mathrm{~L} 3 & \mathrm{~L} 5+\mathrm{L} 6 & \text { L.5 } & \mathrm{L} 7 \\ v 5 & v 5 & v 5 & v s & v S & v s & v S \\ \mathrm{~L} 3 \text { to } \mathrm{L} 8 & \mathrm{~L} 2 & \mathrm{~L} 5 \text { to } \mathrm{L} 8 & \mathrm{~L} 4 & \mathrm{~L} 7 \text { to } \mathrm{L} 8 & \mathrm{~L} 6 & \mathrm{~L} 8\end{array}$

Gonostomatidae

Myctophidae

Gempylidae

Coryphaenidae

Melanostomiatidae

Clupeoidei

Apogonidae

Monacanthidae

Leiognathidae

Platycephalidae

'Mullid-like'

Syngnathidae

Epinephelinae

Lethrinidae

Nemipteridae

Lutjanidae

Fistulariidae

Pomacentridae

Triglidae

Gobiidae

Champsodontidae

Priacanthidae

Scombridae

Paralepidadae

Scorpaenidae

Sphyraenidae

Anthiinae

Synodontidae

Cephalocanthidae

Evermannellidae

Microdesmidae

Carangidae

Hemiramphidae

Lophiiformes

Mullidae

Dussumierínae

Ammodytidae

Schindleriidae

Labridae

Callionymidae

Haemulidae

Opistognathidae

Creediidae

Mugiloididae

Tetraodontidae

Scaridae

Fistularidae

Balistidae

Blenniidae

Pomacanthidae

Chaetodontidae

Paralepididae

Acanthuridae

Holocentridae

Nomeidae

Menidae

Bramidae

Pegasidae

\section{$\therefore$}

$\because$

$\therefore$

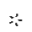

$+$

$\begin{array}{cc}+ & + \\ & + \\ & + \\ + & +\end{array}$

$\therefore$

$\because$

$\because$

$\therefore$

+
+
+
+

+
+
+
+
+
+

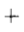

$+$

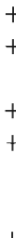

$\because-$

$\therefore$

$\therefore$

$\therefore$

$\therefore$

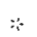

$\because$

$\therefore$

$\therefore$ 
deepwater families Gonostomatidae and Myctophidae decreased in both concentration and frequency in November-December.

The remaining samples were taken only by the Isaacs-Kidd net. They fell into 4 major groups (L5 to 8), categorised by shelf location and time of sampling. These groups contained all except 2 of the Isaacs-Kidd samples taken from the 4 midshelf sites and the 2 inner shelf sites (Fig. 3b). Two of the groups (L5 and L6) were composed mostly of midshelf samples, and 2 (L4 and L8) mostly of inner shelf samples.

The Monacanthidae, Sphyraenidae, Sygnathidae, and Dussumierinae occurred more frequently in samples from the inner shelf (L4 and L8), while all the other 13 diagnostic taxa predominated in midshelf samples (L5 and L6, Table 3). Of these midshelf taxa, 4 were slope or oceanic taxa as adults, and the rest were shelf adults with pelagic eggs.

Two seasonal groups could be distinguished in the midshelf samples: a summer/autumn group (L5) collected between 23 January and 25 April; and a winter/ spring group (L6) taken between 7 June and 28 October. Of the 14 taxa contributing most to the difference between these 2 groups of midshelf samples, all but 2 - the Holocentridae and Acanthuridae predominated in the winter/spring period (L6). Moreover, of the 61 taxa contained in the 2 groups, the mean concentrations of 49 were equal to or greater in the winter/spring group (L6) than those in the summer/ autumn group (L5, Table 2) and number of taxa and total concentration of larvae increased concurrently.

The 2 groups of inner shelf samples were also segregated seasonally. Samples collected between January and February, together with those collected in October, fell into a spring/summer group (L7), while those collected between February and October fell into an autumn/winter group (L8). All of the 12 taxa most responsible for the differences between these 2 groups occurred with greater frequency in the spring/summer group (L7, Table 3) and 39 of the 53 taxa contained in samples in the 2 groups also had greater concentrations in that group (Table 2).

\section{Hydrology}

In the classification of water properties, 4 samples differed from the rest (Fig. 4). The first (number 38) was characterised by very high nitrate and silicate. These characteristics were shared with samples from group $\mathrm{H} 6$ (below) which were also taken from the midshelf and outer shelf sites of the eastern transect in summer. It differed from these samples, however, in containing a substantially lower oxygen concentration. The next 2 $($ Nos 67,68$)$ were typified by very high oxygen and low temperature and salinity, the first of which was shared, but to a lesser extent, by the other winter samples in Group $\mathrm{H} 2$ (below). The magnitude of the differences between these 3 samples and the rest led us to conclude that they represented extreme examples of the general trend shown by the samples contained in Groups H2 and H6. Apart from Sample 11, which had very low salinity and silicate concentrations, the remaining samples were subsequently classified into 6 groups, with characteristic levels of homogeneity in both time and location.

The first group of samples to separate from the rest (H6) contained only 6 samples and was characterised by high nitrate and silicate concentrations, high fluorescence values and low oxygen concentration (Table 4). Samples with these characteristics were taken only to the outer shelf and midshelf sites, where they occurred between December and April, mostly on the eastern transect (Fig. 4). A second small group of 4

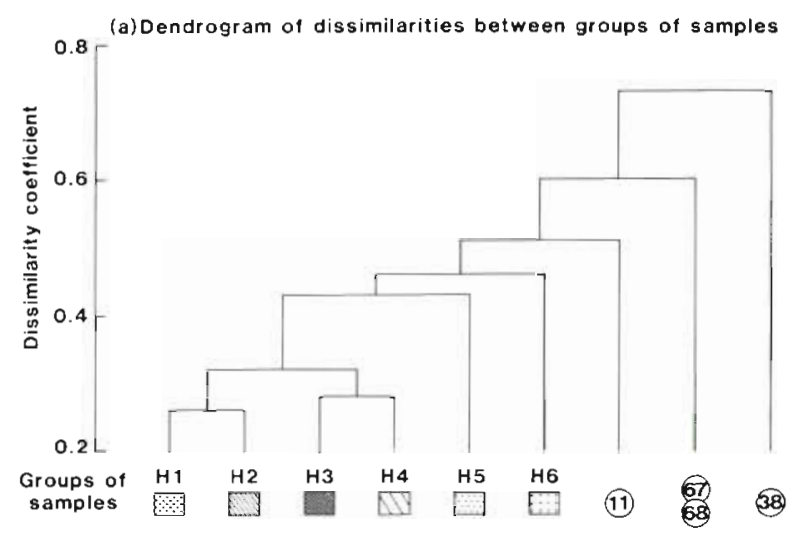

(b) Location of grouped samples in space and time

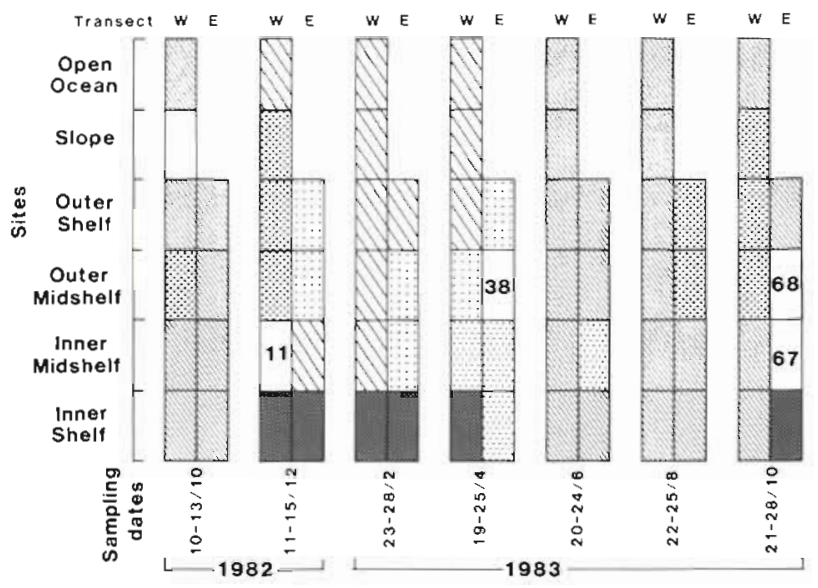

Fig. 4. Classification of the column-averaged water properties of the sampling sites. (a) Dendrogram of dissimilarities. (b) Location and time of occurrence of group of similar samples extracted by the classification. The cells in the columns represent each water sample. Those in columns marked $\mathrm{W}$ come from the western transect. Those in columns marked E come from the eastern transect 
Table 4. Mean values of water properties in each classificatory group 1 to 6

\begin{tabular}{|c|c|c|c|c|c|c|}
\hline \multirow[t]{2}{*}{ Variable } & \multicolumn{6}{|c|}{ Group } \\
\hline & $\mathrm{H} 1$ & $\mathrm{H} 2$ & $\mathrm{H} 3$ & $\mathrm{H} 4$ & $\mathrm{H} 5$ & $\mathrm{H} 6$ \\
\hline Temperature $\left({ }^{\circ} \mathrm{C}\right)$ & 24.35 & 24.39 & 27.69 & 27.50 & 27.35 & 26.78 \\
\hline Salinity (\%o) & 35.02 & 35.03 & 35.55 & 34.92 & 35.09 & 35.01 \\
\hline Oxygen PPM & 4.38 & 4.69 & 4.37 & 4.46 & 4.46 & 4.17 \\
\hline Nitrate $\left(\mu \mathrm{g}-\mathrm{N}\right.$-atom $\left.\mathrm{l}^{-1}\right)$ & 1.98 & 0.39 & 0.28 & 1.06 & 0.56 & 3.80 \\
\hline Silicate $\left(\mu \mathrm{g}\right.$-Si-atom $\left.\mathrm{l}^{-1}\right)$ & 4.31 & 3.77 & 3.77 & 3.33 & 3.69 & 5.12 \\
\hline $\begin{array}{l}\text { In vivo fluorescence } \\
\text { (standardised unit Parker \& Vaudrey [1980]) }\end{array}$ & 78.11 & 69.48 & 106.17 & 62.82 & 211.75 & 113.67 \\
\hline
\end{tabular}

samples was the next to separate in the classification (H5). These samples were all from the inner midshelf and inner shelf sites between April and June and were characterised by extremely high fluorescence values (Table 4).

The remaining samples fell into 2 pairs of groups. One pair (H3 and H4) contained samples all but one of which had been collected between December and April (the summer/autumn groups), while the samples in the other pair ( $\mathrm{H} 1$ and $\mathrm{H} 2$ ) had all been collected between October and December, and between June and October (the winter/spring groups).

Most $(90 \%)$ of the difference between these 2 pairs of groups $(\mathrm{H} 1+\mathrm{H} 2$ vs $\mathrm{H} 3+\mathrm{H} 4)$ was attributable to the overall combination of higher temperature and lower silicate and oxygen concentrations in the $\mathrm{H} 3+$ H4 summer/autumn groups. Of these, H3 contained only samples from the inner shelf sites, and was differentiated from $\mathrm{H} 4$ by the combination of higher in vivo fluorescence values, lower salinity, and lower nitrate concentration.

The groups of samples across the shelf during the summer/autumn period between December and May reflect the stratification of the shelf water column at this time, during which episodic intrusions of colder, nutrient-rich water spread shorewards along the bottom of the shelf. This is reflected in the high nutrient values of Group H6. The high fluorescence values of samples from Group H5 may also have resulted from this input. The water at the inner shelf sites was shallow (about $40 \mathrm{~m}$ ), and since the thermocline occurred at about $40 \mathrm{~m}$ at this time, there was a physical barrier to the spread of offshore nutrients to these regions, resulting in low nitrate and silicate concentrations in samples from Group H3 the summer innershelf samples).

By winter (August to December) stratification had broken down, and relatively uniform conditions to $100 \mathrm{~m}$ occurred over the entire shelf. One group of samples taken during this time from only outer midshelf, outer shelf, and slope sites (Group H1) was characterised by the combination of low oxygen, high nitrate, and high silicate. These characteristics are likely to be due to the breakdown of the summer thermocline, enabling the deeper, nutrient-rich waters that came onto the shelf in summer to mix into the upper layers of the water column.

Samples from the second winter group (H2) occurred across the entire transect at times, indicating a thorough mixing of shelf water to $100 \mathrm{~m}$ from June to October. This may have been related to the onset of the southeast trade winds.

\section{DISCUSSION}

The larvae captured in this study of the North West Shelf reflect the highly diverse fish fauna of the shelf and the contribution of oceanic and deeper-dwelling slope species. The number of families represented by larvae in our samples is as high as any reported for tropical areas, and the number of shelf fish $^{2}$ families is second only to that found in the very diverse coral reef areas of the Great Barrier Reef (Table 5). The number of oceanic and deep benthic families was, as expected, less than that reported in studies of primarily oceanic habitats, for only about $15 \%$ of our samples were taken seaward of the edge of the continental shelf.

The families represented as larvae included many non-eel bony fish families reported as adults from the area (Sainsbury et al. 1985). We also captured 23 families not reported by Sainsbury et al. (1985, unpubl. data), only 3 of which were not oceanic, but failed to catch the larvae of 40 other families also reported from the area as adults by Sainsbury et al. (1985, unpubl. data).

Although this study did not attempt to identify indivicuals below the family level, and despite the usual presence in this geographic region of many species within each family (Sainsbury et al. 1985), and the absence of faunal variability between replicate sam-

\footnotetext{
2 Shelf fishes are defined as those families whose adults live primarily landward of the shelf break (i.e. $200 \mathrm{~m}$ )
} 
Table 5. Number of families represented in larval fish surveys of coastal areas in tropical portions of Atlantic, Pacific and Indian Oceans. All figures exclude eel leptocephali

\begin{tabular}{|c|c|c|c|c|}
\hline Area & $\begin{array}{c}\text { Total } \\
\text { families }\end{array}$ & $\begin{array}{l}\text { Oceanic plus } \\
\text { deep benthic } \\
\text { families }\end{array}$ & $\begin{array}{l}\text { Shelf fish } \\
\text { families }\end{array}$ & Source \\
\hline \multicolumn{5}{|l|}{ Indian Ocean } \\
\hline Northwest (Red Sea, Arabian Sea, Persian Gulf) & 102 & 44 & 58 & Nellen 1973 \\
\hline Southeast (NW continental shelf, Australia) & 103 & 36 & 67 & Present study \\
\hline \multicolumn{5}{|l|}{ Pacific Ocean } \\
\hline Southwest (Great Barrier Reef Lagoon, Australia) & 95 & 22 & 73 & Leis \& Goldman unpubl. \\
\hline Central (Hawaii) & 99 & 43 & 56 & Miller et al. 1979 \\
\hline Eastern tropical & $76^{\circ}$ & 52 & $24^{*}$ & Ahlstrom 1971, 1972 \\
\hline \multicolumn{5}{|l|}{ Atlantic Ocean } \\
\hline Northwest (Caribbean Sea and Gulf of Mexico) & $78-83$ & $34-38$ & $44-45$ & Belyanina 1975, Richards 1984 \\
\hline
\end{tabular}

ples, consistent patterns of dissimilarity were identified between groups of samples which related to specific sampling effects. These effects, in order of magnitude, were: the broad location of sampling (whether on the mid and inner continental shelf or on the outer shelf, slope and off the shelf); the type of sampling gear (whether collected by the Maruchi or the Isaacs-Kidd net); the location of sampling on the shelf (whether inner shelf or midshelf); and the seasons of sampling. There were no consistent longshore differences in species composition or total larval concentration, and no consistent temporal difference on the scale of 2 wk.

A summary description of sample groups resulting from the dissimilarity analysis of the larval fish catches is given in Table 6. Large differences were found between the catches of the Maruchi and Isaacs-Kidd nets. This was expected, but as all comparisons between nets were confounded by temporal factors, it is impossible to determine what differences were due to gear type alone. Inspection of the dendrogram (Fig. 3a) indicates that differences in catch between nets were greater for the inner and midshelf groups of samples than for the oceanic/slope group, despite their overall similarities in taxon abundance (79 and 86 taxa, respectively: Tables $2 \& 3$ ). The significance of this is unclear.

The largest differences in larval fish assemblages were found in the cross-shelf (onshore/offshore) location of sampling sites, the greatest of which was the contrast between the inner and midshelf sites and the outer shelf, slope and oceanic sites (i.e. roughly on either side of the start of the shelf break at 150 to $200 \mathrm{~m}$ ). In general, the water depth at a station seemed a more important determinant of taxonomic composi- tion and group type than did distance from shore. The larvae that characterized the deep water group were of taxa that are oceanic as adults, whereas the larvae that characterized the shelf group were of taxa that live on the shelf as adults. In the northeast Pacific off the Oregon (USA) coast, Richardson \& Pearcy (1977), Richardson \& Stephenson (1978), and Richardson et al. (1980) found similar shelf and oceanic assemblages of fish larvae, often separated by a narrow ecotonal zone that contained what they characterized as a transitional assemblage. Off Oregon, the transition from shelf to oceanic assemblage generally paralleled the $200 \mathrm{~m}$ contour, but varied in its position with time from

Table 6. Summary description of sample groups resulting from dissimilarity analysis

\begin{tabular}{|cl|}
\hline Group & \multicolumn{1}{c|}{ Description } \\
\hline L1 & $\begin{array}{l}\text { Samples taken by Maruchi net at off-shelf and } \\
\text { outer-shelf sites throughout the year, plus } 2 \\
\text { samples taken by Isaacs-Kidd net on the outer } \\
\text { shelf in October } \\
\text { Samples taken by Isaacs-Kidd net at off-shelf } \\
\text { and outer-shelf sites throughout the year }\end{array}$ \\
L3 & $\begin{array}{l}\text { Samples taken by Maruchi net at inner and } \\
\text { midshelf sites in September-October }\end{array}$ \\
L4 & $\begin{array}{l}\text { Samples taken by Maruchi net at inner and } \\
\text { midshelf sites in November-December } \\
\text { L5 }\end{array}$ \\
Samples taken by Isaacs-Kidd net mostly at \\
midshelf sites in January to April \\
L7 & $\begin{array}{l}\text { As L5, but June to October } \\
\text { Samples taken by Isaacs-Kidd net, mostly at } \\
\text { inner-shelf sites in January-February and } \\
\text { October } \\
\text { As L7, but February to October }\end{array}$ \\
L8 &
\end{tabular}


near the coast to well out over the continental slope (Richardson et al. 1980). This variation was attributed to temporal variation in the circulation pattern. On the much broader North West Shelf of Australia (140 to $200 \mathrm{~km}$ as against 25 to $75 \mathrm{~km}$ ), the oceanic assemblage only twice extended to midshelf (November 1982, February 1983), was always present on the slope and open ocean sites, and was present at the most seaward site of each transect 16 of the 21 times it was occupied. In contrast, no inner midshelf assemblage was found seaward of the shelf break, i.e. at the slope or open ocean stations.

The shelf group split into midshelf and inner shelf subgroups (as Richardson et al. [1980] had found in Oregon) but there was no obvious spatial relation between adult habitat and the location of these groups of larvae. The inner shelf group never extended beyond midshelf, but the midshelf group on 3 occasions extended to our most nearshore sites. Similarly, Richardson et al. (1980) distinguished an inner shelf subgroup from an outer shelf subgroup off Oregon.

The coastal assemblages distinguished by Richardson and coworkers were generally restricted to within $18 \mathrm{~km}$ of the shore. They sampled as close as $2 \mathrm{~km}$ from shore; on the North West Shelf we sampled no closer than $31 \mathrm{~km}$. Therefore, we think it likely that an unsampled nearshore pelagic larval fish assemblage exists. If so, the North West Shelf larval fish fauna would be more structured than that of the Oregon shelf. The spatial structure of the larval fish fauna seems, in any case, to be more stable on the North West Shelf of Australia than off Oregon. We can only speculate that these differences are due to the greater width of the North West Shelf.

Little, if any, difference in larval fish assemblages was detected in the longshore direction on the North West Shelf despite marked differences between transects in summer water conditions, and a similar situation was reported off Oregon (Richardson et al. 1980).

The similarities between the results presented here and those from Oregon are striking. They are even more so considering the differences in the fish fauna of the 2 areas and the different taxonomic levels used in the 2 studies (i.e. family $v s$ species). This may indicate that such zonal distributions are a regular feature of relatively straight continental coasts. The only other study comparable to these 2 is that of Loeb et al. (1983) off California and Mexico, but that study emphasized oceanic areas (to $500 \mathrm{~km}$ offshore). Little sampling was done over the continental shelf, and Loeb et al. (1983) did not discuss in detail the recurrent groups that contained larvae of shelf fishes.

Although seasonal structure was clearly subordinate to spatial structure (Fig. 3), seasonal subgroups were found within all the spatial subgroups on the North
West Shelf. The seasonal subgroups were not the same in each spatial group. In the outer shelf/slope/oceanic group, seasonality in assemblage structure was either absent or confounded by the change in sampling gear. In the inner shelf group, the shifts between seasonal subgroups occurred in late summer and early spring. In the midshelf group, the shifts occurred in autumn and some time during late spring or early summer (the exact time is not known because this period was sampled only by the Maruchi net). In both midshelf and inner shelf groups, one seasonal subgroup had markedly higher frequencies of occurrence and concentrations of larvae than the other. These 'peak' periods were spring/summer in the inner shelf group, and winter/spring in the midshelf group. This seasonal increase in a large number of taxa implies a response to one or more environmental parameters that are favourable to adult reproductive activity or to some aspect of larval survival, growth, dispersal or retention. Seasonal variations in nutrient input could be the explanation.

Holloway \& Nye (1985) indicated that in this area the predominant currents are longshore, with a strong southwest direction in autumn and winter, weakening after September when the wind blows chiefly from the west and southwest. At this time the water column becomes stratified with a colder, nutrient-rich, bottom water layer that is less warm than in the winter. Holloway et al. (1985) conclude that this nutrient input derives from cold, deep, nutrient-rich water off the continental shelf. They show that during the summer months (November to April), pulses of cold water pass onto the shelf and persist for 2 to 3 wk concurrently with periods of high nutrient concentration and net inshore flux of water. During this period of stratification, chlorophyll concentrations are maximized at 40 to $80 \mathrm{~m}$ adjacent to the intrusion of high nitrate water (Hallegraeff \& Jeffrey 1984). Such pulses of enrichment were also seen during summer (December to April) in the present study in the top $100 \mathrm{~m}$, particularly at the eastern sites in the midshelf region where unseasonably cold water was associated with high nitrate and silicate concentrations, and high in vivo fluorescence. Samples with high in vivo fluorescence were also taken at inner midshelf and inner shelf sites during this time, with the highest values occurring in samples from April and June.

From the above it may be postulated that from November to April, pulses of high nutrient-rich water enrich the continental shelf particularly to the northeast in a progression from the shelf edge to inshore regions. Due to thermal stratification this water is restricted to the lower part of the water column. However, there is sufficient light at this depth for the phytoplankton to utilize the increased nutrients, and 
increased levels of standing stock were detected by December on the outer shelf and slope regions. By February they occurred on the central shelf, and by April on the inner shelf. The present study also suggests that high nutrient concentrations occur on the outer midshelf and inner midshelf regions after the breakdown of the thermal stratification when bottom nutrients can become dispersed through the water column. The inner shelf is too shallow to receive this pulse of nutrients. Fish larvae caught at the midshelf sites were most concentrated between June and August, but the inner shelf sites had low concentrations during this time. Our expectation that highest abundances of larvae would co-occur with, or slightly lag behind, highest primary production (as indicated by in vivo fluorescence) was only partly realized. However, although the familial composition of the midshelf larval fish group did not vary with the summer differences between transects, it did change to coincide with the change in water column characteristics from winter to summer. Thus some environmental link between seasonal changes in water conditions and reproductive activity of adults or survival of larvae seems likely.

Some larvae were extremely widespread and did not contribute to the patterns found in our analysis. These were the Pleuronectiformes, eel leptocephali and the Bregmacerotidae. The first 2 taxa comprise a number of speciose families, so it is possible that this taxonomic level is too coarse for any pattern to be detected. The Bregmacerotidae, however, which are represented by only 3 species in the area, are known for the abundance and widespread distribution of their larvae (Houde 1981).

The factors that might be most responsible for maintenance of the spatial patterns observed on the North West Shelf are spawning mode (i.e. demersal or pelagic eggs), spawning location, timing of spawning, water circulation in the area, and behaviour of the larvae. Work underway on adult spawning and water circulation on the North West Shelf should shed some light on these aspects. As yet almost nothing is known of the behaviour of the fish larvae from this area.

Off Oregon, Richardson \& Pearcy (1977) proposed that the spawning mode and location of the adults, together with a surface front associated with seasonal upwelling, could help to explain the distributional patterns of larval fishes. Richardson et al. (1980) speculated that a 'kind of cellular circulation pattern exists near and beyond the shelf edge', which could be utilized by the larvae to maintain their distributions.

It remains to be seen if upwelling-related circulatory cells similar to the Oregon model exist on the North West Shelf, or if the larvae are retaining their positions by the utilization of other circulatory features known to occur in the area, such as internal waves or tidal currents. The present study has, however, identified strong patterns in the structure of the larval fish fauna of the North West Continental Shelf of Australia - even on the coarse scale of identification to family, 2monthly sampling, and widely spaced stations. The more detailed analyses of species in families now in progress may provide a better understanding of the patterns already identified. The results of the present study will in turn provide an overall perspective for these more detailed studies.

Acknowledgements. Considerable assistance was given to the authors in the collection of samples. We would particularly like to thank the Master of the R.V. Soela, Captain D. Sheridan, and his crew for assistance in the collection of samples under sometimes difficult conditions, and R. Cowper who set up the sampling gear and sorted the tens of thousands of fish larvae from other zooplankton. We should also like to thank D. Tranter for permission to use his in vivo fluorescence data, and N. Bulleid for informative and helpful discussions relating to the hydrological conditions of the study area. Critical reviews of the manuscript by $R$. E. Johannes, A. R. Jones, and D. McB. Williams were very helpful in improving the manuscript. J. M. Leis was supported by MST grants SO/ 2016 and $83 / 1357$ during this study.

\section{LITERATURE CITED}

Ahlstrom, E. H. (1971). Kinds and abundance of fish larvae in the eastern tropical Pacific, based on collections made on EASTROPAC I. Fish. Bull. U.S. 69: 3-77

Ahlstrom, E. H. (1972). Kinds and abundance of fish larvae in the eastern tropical Pacific on the second multi-vessel EASTROPAC survey, and observations on the annual cycle of larval abundance. Fish. Bull. U.S. 70: 1153-1242

Belyanina, T. N. (1975). Preliminary results of the study of ichthyoplankton of the Caribbean sea and the Gulf of Mexico. Trudy Inst. Okeanol. 100: 127-146. (English Trans. 1981 by AI Ahram Center for Scientific Translations)

Dale, M. B., Lance, G. N., Albrecht, L. (1971). Extensions of information analysis. Aust. Comput. J. 3: 29-34

Fahay, M. P. (1983). Guide to the early stages of marine fishes occurring in the western North Atlantic Ocean, Cape Hatteras to the Southern Scotian Shelf. J. Northwest. Atl. Fish. Sci. 4: 1-423

Fritzsche, R. A. (1978). Development of fishes of the midAtlantic Bight: an atlas of egg, larval and juvenile stages. U.S. Dept Interior Fish. Wildl. Serv., Biol. Serv. Program 5: $1-340$

Hallegraeff, G. M., Jeffrey, S. W. (1984). Tropical phytoplankton species and pigments of continental shelf waters of North and North-West Australia. Mar. Ecol. Prog. Ser. 20: $59-74$

Hardy, J. D., Jr. (1978a). Development of fishes of the midAtlantic Bight: an atlas of egg, larval and juvenile stages. U.S. Dept Interior Fish. Wildl. Serv., Biol. Serv. Program 2: $1-458$

Hardy, J. D., Jr. (1978b). Development of fishes of the midAtlantic Bight: an atlas of egg, larval and juvenile stages. U.S. Dept Interior Fish. Wildl. Serv., Biol. Serv. Program 3: $1-340$

Holloway, P. E., Nye, H. C. (1985). Leuwin Current and wind 
distribution on the southern part of the Australian North West Shelf between January 1982 and July 1983. Aust. J. mar. Freshwat. Res. 36: 123-137

Holloway, P. E., Humphries, S. E., Atkinson, M., Imberger, J. (1985). Mechanisms for nitrogen supply to the Australian North-West Shelf. Aust. J. mar. Freshwat. Res. 36: 753-764

Houde, E. D. (1981). Distribution and abundance of four types of codlet (Pisces: Bregmacerotidae) larvae from the eastern Gulf of Mexico. Biol. Oceanogr. 1: 81-103

Johnson, G. D. (1978). Development of fishes of the midAtlantic Bight: an atlas of egg, larval and juvenile stages. U.S. Dept Interior Fish. Wildl. Serv., Biol. Serv. Program 4: $1-311$

Jones, P. W., Martin, F. D., Hardy, J. D., Jr. (1978). Development of fishes of the mid-Atlantic Bight: An atlas of egg larval and juvenile stages. U.S. Dept Interior Fish. Wildl. Serv., Biol. Serv. Program 1: 1-366

Lance, G. N., Milne, P. W., Williams, W. T. (1968). Mixed data classificatory programs. III. Diagnostic systems. Aust. Comput. J. 1: 178-181

Lance, G. N., Williams, W. T. (1967a). Mixed data classificatory programs. I. Agglomerative systems. Aust. Comput J 1: $15-20$

Lance, G. N., Williams, W. T. (1967b). A general theory of classificatory sorting strategies. I. Hierarchical systems. Aust. Comput. J. 9: 373-380

Leis, J. M., Rennis, D. S. (1983). The larvae of Indo-Pacific Coral Reef fishes. New South Wales University Press and University of Hawaii Press, Sydney \& Honolulu

Loeb, V., Smith, P. E., Moser, H. G. (1983). Recurrent groups of larval fish species in the California Current area. CALCOFI Reports 24: 152-179

Martin, E. D., Drewry, G. E. (1978). Development of fishes of the mid-Atlantic Bight: An atlas of egg, larval and juvenile stages. U.S. Dept Interior Fish. Wildl. Serv., Biol Serv. Program 6: 1-416

Miller, J. M., Watson, W., Leis, J. M. (1979). An atlas of common nearshore manine fish larvae of the Hawaiian Islands. University of Hawaii Sea Grant Program, Honolulu, Miscellaneous Report 80-02: 1-179
Nakai, Z. (1962). Apparatus for collecting macroplankton in the spawning surveys of 'Iwashi' (sardine, anchovy and round herring) and others. Bull. Tokai reg. Fish. Res. Lab. 9: $221-237$

Nellen, W (1973). Fischlarven des Indischen Ozeans. Meteor' Forsch.-Ergebnisse, Reihe D. No. 14: 1-66

Parker, R. R., Vaudrey, D. J. (1980). A proposed reference standard for in vivo chlorophyll a fluometry. CSIRO Division of Fisheries and Oceanography, Cronulla, Australia, Report No. 125

Richards, W. J. (1984). Kinds and abundances of fish larvae in the Caribbean Sea and adjacent waters. NOAA Tech. Rept., NMFS Special Scientific Report Fisheries 776: 1-54

Richardson, S. L., Pearcy, W. G. (1977). Coastal and oceanic larvae in an area of upwelling off Yaquina Bay, Oregon. Fish. Bull. U.S. 75 (1): 125-145

Richardson, S. L., Stephenson, W. (1978). Larval fish data: a new approach to analysis. Oregon State Univ. Sea Grant College Prog. ORESU T-78-002: 1-16

Richardson, S. L., Laroche, J. L., Richardson, M. D. (1980). Larval fish assemblages and associations in the north-east Pacific ocean along the Oregon coast, winter-spring 1972-1975. Estuar. coast. mar. Sci. 11: 671-699

Sainsbury, K. J., Kailola, P. J., Leyland, G. G. (1985). Continental shelf fishes of northern and north-western Australia; an illustrated guide. Cholson Pownell Press, Canberra

Sandland, R. L., Young, P. C. (1979a). Probabalistic tests and stopping rules associated with hierarchical classification techniques. Aust. J. Ecol. 4: 399-406

Sandland, R. L., Young, P. C. (1979b). Tables of probabilities associated with the fission of replicate samples in classifications. CSIRO Division of Fisheries and Oceanography, Cronulla, Australia, Report No. 108

Smith, P. E., Richardson, S. L. (1977). Standard techniques for pelagic fish egg and larva surveys. FAO Fisheries Technical Paper 175. FAO, Rome

Williams, W T., Lambert, J. M., Lance, G. N. (1966). Multivariate methods in plant ecology. $\mathrm{V}$. Similarity analyses and information analysis. J. Ecol. 54: 427-445 